\title{
Accumulation of some heavy metals and its effect on hematological indices of fresh water fish, Oreochromis niloticus
}

\author{
El-Sayed El-Bastamy El-Sayed \\ Central Laboratory for Environmental Quality Monitoring, National Water Research \\ Center, P. O. Bx 13621/6, El-Kanater, Egypt.
}

\section{ABSTRACT}

Accumulation of some heavy metals (copper, iron, manganese, nickel and zinc) and its effect on the hematological indices on the freshwater fish (Oreochromis niloticus) were studied. Fish Samples were collected from the River Nile near ElKanater El-Khyria and contaminated water from Iron and Steel Basin in El-Safe Village near Helwan, south of Cairo. Results of this study showed that there was a significant difference between the water qualities indices among the two different locations. Meanwhile, fish samples that collected from polluted location showed high values for the hematological indices namely hemoglobin $(\mathrm{Hb})$, red blood count (RBC), hematocrit (Hct), white blood cell count (WBC) and erythrocyte. Moreover, the concentrations of heavy metals were also high in the fish. However, the levels of the heavy metal accumulation were within the maximum permissible limit for human consumption (FAO, 1992). The order of bioaccumulation of such metals in the liver of fish were $\mathrm{Fe}>\mathrm{Zn}>\mathrm{Cu}>\mathrm{Mn}>\mathrm{Ni}$. It was concluded for this study that the discharge of different types of wastes, especially heavy metals from washing process of Iron and Steel in Helwan Company deteriorated the water quality and consequently affecting the fish. It is recommended to treat the different wastes before discharging to Iron and Steel Basin in ElSafe Village.

Keywords: Heavy metals, fish, accumulation, hematology.

\section{INTRODUCTION}

Tilapia fish are likely to be the most important of all cultured fish in the $21 \mathrm{st}$ century. They are farmed in every manner from semi extensive to super-intensive farms (Fitzsimmons, 2000).

Most heavy metals which are released into the environment find their way into the aquatic environment as a result of direct input, atmospheric deposition and erosion due to rainwater, therefore aquatic animals may be exposed to elevated levels of heavy metals due to their wide use for anthropogenic purposes (Kalay and Canli, 2000). Those metals are non-biodegradable and once they enter the environment, bioaccumulation occurs in the tissue of fish tissue by means of metabolic and biosorption processes.

Contamination with such heavy metals has long been recognized as a serious pollution problem due to their persistence and accumulative nature. It may have devastating effects on the ecological balance of the recipient environment and a diversity of aquatic organisms (Farombi et al., 2007).

As the concentration of metal increases, the accumulation of metal and its damage effect increase (Buschiazzoa et al., 2004).

The industrial drainage and sewage water revealed the highest concentrations of heavy metals followed by agriculture drainage water. The muscles, gills, kidney and liver tissues of fish samples collected from industrial drainage and sewage canals had the highest levels of heavy metal residues followed by agriculture drainage (El-Sayed 
et al., 2011). In a polluted aquatic ecosystem, when the fish are exposed to high levels of heavy metals, they tend to take these metals that may accumulate in their tissues and may ultimately reach concentration hundreds or thousands of times above those measured in the water, sediment and food (Osman et al., 2007 and Godwin et al., 2003).

Toxic heavy metal contamination mostly occurs in aquaculture and frequently occurs in groundwater, rivers, estuaries, wetland and coastal areas. The toxicity of those elements is due to their ability to cause, oxidative damage to living tissues, while environmental changes can have significant effects on the immune system. Seasonal and diurnal changes in immune response and disease prevalence have been reported in wild fish; these factors being changes in temperature and light density (Bowden 2008).Also, it can cause dermatological diseases, skin cancer and internal cancers (liver, kidney, lung and bladder), cardiovascular disease, diabetes, and anaemia. Transport of metals in fish occurs through the blood where the ions are usually bound to proteins.

This work was aimed to determine copper, iron, manganese, nickel, and zinc in flesh, liver of fishes and its effect on some hematological indices in the fresh water fish (O. niloticus).

\section{MATERIALS AND METHODS}

\section{Water samples}

Water and fish samples were collected in summer during June 2014 from two different locations as shown in Table (1). The first location was River Nile (ElKanater El-Khyria as control) which represented unpolluted water and the second location was Iron and Steel Basin in El Safe Village near Helwan which represented the polluted water.

Five water samples were collected from each location in Polyethylene containers of two-liter capacity. The water samples were preserved via adding concentrated nitric acid to reduce the $\mathrm{pH}$ below 2 to prevent the microbial reactions. Water analysis was achieved according to the standard methods for examination of water and wastewater (APHA, 2005).

Table 1: Locations of water and fish sampling

\begin{tabular}{|c|c|c|c|c|}
\hline \multirow{2}{*}{ Location } & \multicolumn{2}{|c|}{$\begin{array}{c}\text { No. of sample } \\
\text { colleted }\end{array}$} & Site & Coordinates \\
\cline { 2 - 3 } & water & fish & & \\
\hline \multirow{2}{*}{ I } & 5 & 10 & $\begin{array}{c}\text { River Nile at El-Kanater El-Khyria (unpolluted, } \\
\text { as control) }\end{array}$ & $\begin{array}{c}30^{\circ} 11^{\prime} 53^{\prime \prime} \mathrm{N} \\
31^{\circ} 07^{\prime} 28^{\prime \prime} \mathrm{E}\end{array}$ \\
\hline II & 5 & 10 & Iron and Steel Basin in ElSafe Village (polluted) & $\begin{array}{c}29^{\circ} 43^{\prime} 14^{\prime \prime} \mathrm{N} \\
31^{\circ} 19^{\prime} 48^{\prime \prime} \mathrm{E}\end{array}$ \\
\hline
\end{tabular}

\section{Fish samples}

Ten fish, tilapia, Oreochromis niloticus, weighting 75-90 g, were collected from each location by using gill net and transferred in two separate aerated tanks to Central Laboratory for Environmental Quality Monitoring.

\section{Samples preservation:}

Water samples in the collecting bottles were kept directly in a refrigerator at +4 ${ }^{\circ} \mathrm{C}$. Whereas After catching the fish samples, fish were kept in plastic bags, tied well, transported directly to the laboratory and kept frozen in a deep freezer at $-20^{\circ} \mathrm{C}$. 


\section{Tested parameters:}

Fish weight and total length were recorded individually for the nearest one gram and centimeter, respectively according to Abdelhamid (1996) for all fish. Five water samples collected from each location were analyzed physico-chemically and the analyses for the heavy metals $(\mathrm{Cu}, \mathrm{Fe}, \mathrm{Mn}, \mathrm{Ni}$ and $\mathrm{Zn})$. Analyses of physico-chemical parameters of water were carried out according to APHA (2005) including pH (WTW inolab 315i, Germany), temperature (temp.), electric conductivity (EC), and total dissolved solids (TDS) using WTW model 315i, Germany, dissolved oxygen (DO) using WTW model 310i, Germany, carbonate $\left(\mathrm{CO}_{3}\right)$, and bicarbonate $\left(\mathrm{HCO}_{3}\right)$ were volumetrically determined by titration method $\left(0.02 \mathrm{~N} \mathrm{H}_{2} \mathrm{SO}_{4}\right.$ with phenol phethalein and methyl orange as indicators), ammonia (ORION model 9512 attached to Benchtop Ion Analyzer, ORION model EA 940 with built-in stirrer, U.S.A), major anions such as chloride $\left(\mathrm{Cl}^{-}\right)$, sulfate $\left(\mathrm{SO}_{4}^{--}\right)$, and nitrate $\left(\mathrm{NO}_{3}{ }^{-}\right)$were determined in water samples using ion chromatography (IC) Model DX-600, USA. Major cations $\left(\mathrm{Na}^{+}, \mathrm{K}^{+}, \mathrm{Ca}^{++} \& \mathrm{Mg}^{++}\right)$and heavy metals $(\mathrm{Cu}, \mathrm{Fe}, \mathrm{Mn}, \mathrm{Ni}$, and $\mathrm{Zn})$ were determined using the Inductivity Coupled Plasma (ICP-OES 5300 DV U.S.A). Biological oxygen demand (BOD) in the water samples was determined using an ORION BOD Fast Respirometry System (model 890, Germany) with a measuring range 0-4000 mg/l at $20^{\circ} \mathrm{C}$ incubation in a thermostatic incubator chamber (model WTW, Germany), While Chemical oxygen demand (COD) was measured by applying Closed Reflux colorimetric method, using a spectrophotometer at $600 \mathrm{~nm}$.

About 10 fish were caught from each location, weight and total length for each fish were recorded, and then the fish was blotted carefully and the blood was collected from the heart anaerobically without narcosis. Part of the blood was collected in heparinized syringes for determination of blood parameters. The other part was collected via non heparinized syringes and directly transported into tubes. After one hour, the tubes were centrifuged at $3000 \mathrm{rpm}$ for $15 \mathrm{~min}$ by Biofugu Centrifuge and serums were separated and frozen at $-20^{\circ} \mathrm{C}$ for biochemical assays (Adakole, 2012).

Livers of fish from each location were removed and dried at $80^{\circ} \mathrm{C}$ till constant weight. Then, they were digested by using Microwave Labstation MLS- 1200 mega (Reagent used were $\mathrm{HNO}_{3} 65 \%$ and $\mathrm{H}_{2} \mathrm{O}_{2} 30 \%$ ). The concentration of heavy metals (residues) was estimated by using Inductivity Coupled Plasma ICP OES 5300 DV (Chandanshive et al., 2012).

\section{Statistical Analysis}

The results obtained from both locations (water sample, and hematological indices and heavy metals content in the fish) were statistically analyzed to determine the significant differences by using independent t-test sample (SPSS version 7.0.1 copyright SPSS INC1997).

\section{RESULTS AND DISCUSSION}

The water quality parameters such as temperature, $\mathrm{pH}$, electrical conductivity, total dissolved solids, alkalinity, dissolved oxygen, ammonia, biochemical oxygen demand, chemical oxygen demand and heavy metals $(\mathrm{Cu}, \mathrm{Fe}, \mathrm{Mn}, \mathrm{Ni}$, and $\mathrm{Zn})$ were measured in both unpolluted and polluted locations as shown in Table (2). The present results showed that the water quality in the polluted location was significantly different compared to the unpolluted location in the Nile River. The mean values of both physical and chemical water parameters tended to be high in the polluted Iron and Steel Basin. The increase of water temperature was highly related to the outlets of Helwan Company that discharges directly the heated water to Iron and Steel Basin. 
While, values of both electrical conductivity (EC) and total dissolved solid (TDS) were above the permissible limits of the law 48/1982, which reflect the strong effect of the effluents discharged from Helwan Company for Iron and Steel that leads to the increase of the total dissolved solids and ionic salts by using the water during the manufacturing process (cooling and wash the steel and iron rods).

Table 2: Mean values of chemical properties in the surface water of River Nile and Iron and Steel Basin

\begin{tabular}{|c|c|c|c|c|c|c|}
\hline \multirow[b]{2}{*}{ property } & \multirow[b]{2}{*}{ df } & \multicolumn{2}{|c|}{ Mean } & \multicolumn{2}{|c|}{ Std. Error } & \multirow[b]{2}{*}{$\begin{array}{l}\text { P-value } \\
\text { (2-tailed) }\end{array}$} \\
\hline & & $\begin{array}{c}\text { River Nile } \\
\text { (El-Kanater } \\
\text { El-Khyria) }\end{array}$ & $\begin{array}{c}\text { Iron and } \\
\text { Steel Basin }\end{array}$ & $\begin{array}{c}\text { River Nile } \\
\text { (El-Kanater } \\
\text { El-Khyria) }\end{array}$ & $\begin{array}{c}\text { Iron and } \\
\text { Steel Basin }\end{array}$ & \\
\hline Temperature $\left({ }^{0} \mathrm{C}\right)$ & 4 & 27.10 & 29.14 & 0.158 & 0.09 & 0,00 \\
\hline PH & 4 & 8.09 & 8.05 & 0.005 & 0.003 & 0.003 \\
\hline $\mathrm{HCO}_{3}^{-} \mathrm{mg} \mathrm{l}^{-1}$ & 4 & 155.80 & 178.40 & 2.31 & 1.43 & 0.00 \\
\hline EC $\mathrm{dS} \mathrm{m}{ }^{-1}$ & 4 & 0.328 & 3.198 & 0.002 & 0.005 & 0.00 \\
\hline Ammonia $\mathrm{mg} \mathrm{l}^{-1}$ & 4 & 2.00 & 8.26 & 0.13 & 0.15 & 0.00 \\
\hline Dissolved Oxygen $\mathrm{mg} \mathrm{l}^{-1}$ & 4 & 6.70 & 2.60 & 0.38 & 0.24 & 0.00 \\
\hline Biological oxygen demand $\mathrm{mg} \mathrm{l}^{-1}$ & 4 & 4.4 & 14.6 & 0.24 & 0.50 & 0.00 \\
\hline Chemical oxygen demand $\mathrm{mg} \mathrm{l}^{-1}$ & 4 & 7.40 & 22.40 & 0.25 & 0.37 & 0.00 \\
\hline $\mathbf{C a}^{2+} \mathrm{mg} \mathrm{l}^{-1}$ & 4 & 23.76 & 289.8 & 1.25 & 0.80 & 0.00 \\
\hline $\mathbf{K}^{+} \quad \mathrm{mg} \mathrm{l}^{-1}$ & 4 & 3.80 & 11.4 & 0.48 & 0.60 & 0.001 \\
\hline $\mathbf{M g}^{2+} \mathrm{mg} \mathrm{l}^{-1}$ & 4 & 12.82 & 38.6 & 0.48 & 0.50 & 0.00 \\
\hline $\mathrm{Na}^{+} \quad \mathrm{mg} \mathrm{l}^{-1}$ & 4 & 19.80 & 319.19 & 0.66 & 0.58 & 0.00 \\
\hline $\mathbf{C I}^{-} \quad \mathrm{mg} \mathrm{l}^{-1}$ & 4 & 22.4 & 490 & 0.81 & 0.63 & 0.00 \\
\hline $\mathbf{N O}_{3}^{-} \mathrm{mg} \mathrm{l}^{-1}$ & 4 & 0.21 & 7.20 & 0.042 & 0.96 & 0.00 \\
\hline $\mathbf{N H}_{4}^{+} \mathrm{mg} \mathrm{l}^{-1}$ & 4 & 2.00 & 5.26 & 0.15 & 0.13 & 0.00 \\
\hline $\mathbf{S O}_{4}{ }^{2-} \mathrm{mg} \mathrm{l}^{-1}$ & 4 & 15.40 & 739.60 & 0.92 & 0.74 & 0.00 \\
\hline $\mathbf{C u} \quad \mathrm{mg} \mathrm{l}^{-1}$ & 4 & 0.008 & 0.018 & 0.001 & 0.001 & 0.00 \\
\hline $\mathbf{F e} \quad \mathrm{mg} \mathrm{l}^{-1}$ & 4 & 0.007 & 0.486 & 0.001 & 0.015 & 0.00 \\
\hline Mn $\quad \mathrm{mg} \mathrm{l}^{-1}$ & 4 & 0.006 & 0.018 & 0.001 & 0.001 & 0.00 \\
\hline $\mathrm{mg} \mathrm{l}^{-1}$ & 4 & 0.004 & 0.010 & 0.001 & 0.001 & 0.00 \\
\hline $\mathbf{Z n} \quad \mathrm{mg} \mathrm{l}^{-1}$ & 4 & 0.004 & 0.0088 & 0.001 & 0.001 & 0.00 \\
\hline
\end{tabular}

- $\quad \mathrm{df}=$ degree of freedom, Std. Error $=$ standard error of the mean, P-value =attained level of significance

- $\quad$ Bold Value $(\mathrm{P})>0.05$ - Italic Value $(\mathrm{P})<0.05$

Also, the increase of ammonia within the polluted Iron and Steel Basin might be related to the domestic effluents from houses and accumulations of organic matter discharges from Helwan Company (Bolalak and Frankowaski, 2003). In addition, such increase might relate to excessive application rates of sewage discharge and industrial wastes as well as microorganism activities in decomposition of residues and fixation of atmospheric nitrogen (Galloway et al., 2003). Exposure to ammonia may cause destruction of immune system, osmoregulatory disturbance, abnormalities structure of tissues and growth rate (Russo and Thurston, 1991). Furthermore, the present results showed that Helwan Company caused depletion of the dissolved oxygen which was far below standards of law 48/1982. This depletion may enhance the toxicity of ammonia on fish and other aquatic organisms, especially in the existence of high temperature and $\mathrm{pH}$ (Schwarzenbach, et al. 2003). It is also clear that aerobic bacteria can be replaced by anaerobic bacteria as the result of the depletion of the oxygen. These anaerobic conditions may cause disagreeable odors due to the production of gases, $\mathrm{H}_{2} \mathrm{~S}, \mathrm{NH}_{3}$ and $\mathrm{CH}_{4}$ (El- Sherbini, et al. 1997).

Concerning the biological oxygen demand (BOD) and the chemical oxygen demand (COD), the present results showed that in the polluted water they increased to 
the concentration of $14.6 \pm 0.50 \mathrm{mg} \mathrm{l}^{-1}$ and $22.40 \pm 0.37 \mathrm{mg} \mathrm{l}^{-1}$, respectively. These results coincide with the finding of Abdo (2005) who recorded high levels of BOD and COD in Abu Za'baal Ponds in Elqalyubia Governorate. The increase of the BOD and COD in polluted sector was higher than the permissible limits of law 48/1982. BOD and COD are useful indicator for organic pollution in the rivers (Loigu and Leisk, 1996). High BOD and COD levels in polluted sectors are related to the existence of high bacterial load and organic matters as well as relative high temperatures which enhance the enumeration of bacteria.

The concentration of copper, iron, manganese, nickel, and zinc recorded higher levels in the polluted sector than River Nile at El-Kanater El-Khyria. It was highly attributed to intense human activities and industrial effluents from Helwan Company for Iron and Steel and the increase of $\mathrm{pH}$ and mobilization of metals from sediment to water (Clare et al., 2007).

Previous studies showed that the bioaccumulation of heavy metals does not only depend on the structure of the organ, but also on the interaction between metals and the target organs (Mersch et al., 1993). El-Naggar et al., (2009) observed that fish could accumulate trace metals and act as indicators of pollution. In the present results, the mean concentration of the heavy metals $(\mathrm{Cu}, \mathrm{Fe}, \mathrm{Mn}, \mathrm{Ni}$, and $\mathrm{Zn})$ tended to be significantly high in the liver of fish which collected from the polluted water as shown in Table (3). The order of accumulation of such heavy metals was $\mathrm{Fe}>\mathrm{Zn}>\mathrm{Cu}>$ $\mathrm{Mn}>\mathrm{Ni}$. However, these concentrations were within the permissible limit for human consumption according to the standard mentioned. The results recorded for copper and iron in the control and polluted locations were $0.005 \pm 0.47-0.085 \pm 8.27,0.004$ $\pm 0.5-0.735 \pm 7.05 \mathrm{mg} \mathrm{kg}^{-1}$ respectively. These results coincide with the finding of Ibrahim and Mahmoud (2005), Tayel et al., (2008), Yacoub (2007), Ibrahim and Tayel, (2005) and Carbonell et al., (1998) who detected high levels of copper and iron in fresh water fishes collected from different contaminated water. Also, the results match with the finding of Haggag et al., (1993) and Yacoub (2007) who observed the free metal iron concentration and thereby lead to accumulation of iron ligand protein (Hemosidrin) scattered in liver of fish which exposed to high iron concentration.

Table 3: Heavy metals concentration of the $O$. niloticus liver from water of River Nile and Iron and Steel Basin

\begin{tabular}{|c|c|c|c|c|c|c|c|}
\hline \multirow[b]{2}{*}{$\begin{array}{l}\text { Property } \\
(\mathrm{mg} / \mathrm{kg})\end{array}$} & \multirow[b]{2}{*}{ df } & \multirow[b]{2}{*}{$\begin{array}{l}\text { Permissible } \\
\text { limit } \\
\text { FAO (1983) }\end{array}$} & \multicolumn{2}{|c|}{ Mean } & \multicolumn{2}{|c|}{ Std. Error } & \multirow[b]{2}{*}{$\begin{array}{c}\text { P-value } \\
\text { (2-tailed) }\end{array}$} \\
\hline & & & $\begin{array}{c}\text { River Nile } \\
\text { (El-Kanater } \\
\text { El-Khyria) }\end{array}$ & $\begin{array}{c}\text { Iron and } \\
\text { Steel Basin }\end{array}$ & $\begin{array}{c}\text { River Nile } \\
\text { (El-Kanater } \\
\text { El-Khyria) }\end{array}$ & $\begin{array}{c}\text { Iron and } \\
\text { Steel Basin }\end{array}$ & \\
\hline Copper & 9 & 30 & 0.005 & 0.085 & 0.47 & 8.27 & 0.002 \\
\hline Iron & 9 & 30 & 0.0045 & 0.735 & 0.50 & 7.05 & 0.00 \\
\hline Manganese & 9 & & 0.0042 & $\mathbf{0 . 0 2 0 7}$ & 0.37 & 3.51 & 0.009 \\
\hline Nickel & 9 & & 0.002 & 0.0021 & 0.001 & 0.34 & 0.002 \\
\hline Zinc & 9 & $\overline{40}$ & 0.0066 & 0.179 & 0.10 & 1.06 & 0.00 \\
\hline
\end{tabular}

- $\quad \mathrm{df}=$ degree of freedom, Std. Error $=$ standard error of the mean, P-value =attained level of significance

- $\quad$ Bold Value $(\mathrm{P})>0.05$ - Italic Value $(\mathrm{P})<0.05$

Manganese is considered as an essential constituent for bone structure, reproduction and normal functioning of the enzymes system, while it is toxic only when present in higher amount, but at low level is considered as micronutrient, (Doherty et al., 2010). The results showed that manganese accumulated with high concentration in the liver of fish obtained from Iron and Steel Basin $(0.0042 \pm 0.37-$ 
$0.0207 \pm 3.51 \mathrm{mg} \mathrm{kg}^{-1}$ in control and polluted locations respectively. These results agree with those obtained by Yacoub, (2007) who determined high concentration of manganese in fresh water fishes in Cairo and Kalubia governorates.

Nickel is non-essential element and higher concentrations can occur in aquatic organisms close to anthropogenic sources. It is toxic even at low concentrations and has no known function in biochemical processes and it is known to inhibit active transport mechanisms, involving adenosine triphosphate (ATP), to depress cellular oxidation reduction reactions and to inhibit protein synthesis (Burden et al., 1998). The study results showed that the concentration of nickel was high in the liver of fish that collected from the polluted basin $\left(0.0021 \pm 0.34 \mathrm{mg} \mathrm{kg}^{-1}\right)$. Nickel inhibits the impulse conductivity by inhibiting the activities of monoamine oxidase and acetylcholine esterase to cause pathological changes in tissue and organs (Rubio et al., 1991) and impair the embryonic and larval development of fish species (Dave and Xiu, 1991).

Also, the results showed that zinc was highly accumulated in the liver $(0.179 \pm$ $\left.1.06 \mathrm{mg} \mathrm{kg}^{-1}\right)$ of fish that collected from the polluted sector compared with control location $\left(0.0066 \pm 0.1 \mathrm{mg} \mathrm{kg}^{-1}\right)$. The fish can take up the zinc directly from water, especially by its mucous and gills (Hamed, 1998). The relatively higher zinc concentration in the liver of the different fish species may be due to the role of zinc as an activator of numerous enzymes present in the liver as recorded by Yacoub, (2007) and Cogun et al., (2005).

Concerning the hematology, it is used as an index of fish health status in number of fish species to detect physiological changes following different stress conditions like exposure to pollutants, diseases, metals, hypoxia (Duthie and Tort, 1985).

The results showed that in the freshwater Oreochromis niloticus which collected from the Iron Steel Basin, the mean values of hemoglobin, white blood cells (WBC), red blood cells (RBC), hematocrit (HCT), corpuscular volume (MCV), the mean corpuscular hemoglobin $(\mathrm{MCH})$, and mean corpuscular hemoglobin concentration (MCHC), were significantly higher than that in the fish which collected from the Nile River as shown in Table (4). Also the results showed that in fish which collected from the contaminated water, the platelets were significantly higher than that in fish which collected from the Nile River (Table 4). Such increases were highly related to the pollutants especially heavy metals and reduction of dissolved oxygen in water. The reduction of oxygen generally expands synthesis of hemoglobin, releases of blood cells from storage sites, and enhances erythropoiesis. Similar results were recorded by (Mehjbeen, and Nazura 2013) and Shah (2006), who reported significant increases in the red blood cells, hematocrit and platelets in Tinca tinca when it was exposed to heavy metals. The significant increases in the $\mathrm{WBC}$ may be as a result of intensive secretion of corticosteroid hormones (Dutta and Kaviraj, 1996). The secretion of these hormones is a nonspecific response to any environmental stressor which including the pollutants. Similarly, when the Tilapia zillii is exposed to high level of nickel, the fish reveals immunological defense by increasing the number of lymphocytes (Mourad et al., 1999). In addition, the increases in mean corpuscular volume (MCV), mean corpuscular hemoglobin $(\mathrm{MCH})$, and mean corpuscular hemoglobin concentration (MCHC) in the present results may relate to a defensive mechanisms against the toxic effect of heavy metals which cause disturbances to the metabolic and the hemopoitic activities in fish (Javed and Usmani, 2013). Also the results of this study showed that when the fish was exposed to low dissolved oxygen, the number of MCV and WBC 
increased as a result of (Praveena et al., 2013) who reported an increase of MCV in Labeo Rohita as a result of hypoxic condition.

Table 4: Hematological parameters of the O. niloticus from water of River Nile and Iron and Steel Basin

\begin{tabular}{|c|c|c|c|c|c|c|c|}
\hline & \multirow[b]{2}{*}{ property } & \multirow[b]{2}{*}{ df } & \multicolumn{2}{|c|}{ Mean } & \multicolumn{2}{|c|}{ Std. Error } & \multirow[b]{2}{*}{$\begin{array}{c}\text { P-value } \\
\text { (2-tailed) }\end{array}$} \\
\hline & & & $\begin{array}{c}\text { River Nile } \\
\text { (El-Kanater } \\
\text { El-Khyria) }\end{array}$ & $\begin{array}{l}\text { Iron and } \\
\text { Steel Basin }\end{array}$ & $\begin{array}{c}\text { River Nile } \\
\text { (El-Kanater } \\
\text { El-Khyria) }\end{array}$ & $\begin{array}{c}\text { Iron and } \\
\text { Steel Basin }\end{array}$ & \\
\hline \multicolumn{2}{|c|}{ Hemoglobin (g/dl) } & 9 & 5.13 & 5.88 & 0.07 & 0.16 & 0.008 \\
\hline \multicolumn{2}{|c|}{ Hematocrit (\%) } & 9 & 14.91 & 19.54 & 0.24 & 0.38 & 0.00 \\
\hline \multicolumn{2}{|c|}{ WBCs $\left(\times 10^{3}\right.$ cells $\left./ \mathrm{mm}^{3}\right)$} & 9 & 178.60 & 215.6 & 3.77 & 3.076 & 0.00 \\
\hline \multicolumn{2}{|c|}{ RBCs $\left(\times 10^{6}\right.$ cells $\left./ \mathrm{mm}^{3}\right)$} & 9 & 1.73 & 2.02 & 0.056 & 0.071 & 0.015 \\
\hline \multirow[b]{3}{*}{ 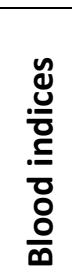 } & $\operatorname{MCV}\left(\mu^{3}\right)$ & 9 & 90.18 & 96.78 & 0.18 & 0.06 & 0.019 \\
\hline & MCH (pg) & 9 & 30.48 & 29.26 & 0.51 & 1.51 & 0.021 \\
\hline & $\operatorname{MCHC~(g/dl)~}$ & 9 & 32.82 & 30.24 & 0.48 & 1.39 & 0.024 \\
\hline \multicolumn{2}{|c|}{ Platelets(Count) } & 9 & 121.60 & 185.00 & 1.03 & 2.90 & 0.00 \\
\hline
\end{tabular}

- $\mathrm{df}=$ degree of freedom, Std. Error $=$ standard error of the mean, P-value =attained level of significance

- $\quad$ Bold Value $(\mathrm{P})>0.05$ - Italic Value $(\mathrm{P})<0.05$

The water pollution leads to damage the tissues and organs of fish, some specific cellular enzymes would leak into the blood (Zikic et al., 1997). The most serum enzymes were significantly elevated in response to ambient water pollution (Sabae and Rabeh, 2006). The results (Table 5) showed that there were increases in serum AST \& ALT concentration in fishes collected from Iron and Steel Basin in ElSafe Village, than recorded in River Nile at El-Kanater El-Khyria. These increases could by attributed to the environmental pollutants of heavy metal and organic substance in water (Matsuo et al., 2004). Similar findings were reported by Hadi et al. (2009), who found that the increase in aluminum cause a significant increase in the activities of serum AST and ALT. The levels of ALT in O. niloticus seem to be elevated in response to the rise in ammonia-in ambient water (Sharsher, 2011).

Table 5: Biochemical parameters of the O. niloticus from water of River Nile and Iron and Steel Basin

\begin{tabular}{|c|c|c|c|c|c|c|}
\hline \multirow{2}{*}{ property } & \multirow{2}{*}{ df } & \multicolumn{2}{|c|}{ Mean } & \multicolumn{2}{c|}{ Std. Error } & \multirow{2}{*}{$\begin{array}{c}\text { P-value } \\
\text { (2-tailed) }\end{array}$} \\
\cline { 3 - 6 } & & $\begin{array}{c}\text { River Nile } \\
\text { (El-Kanater } \\
\text { El-Khyria) }\end{array}$ & $\begin{array}{c}\text { Iron and } \\
\text { Steel Basin }\end{array}$ & $\begin{array}{c}\text { River Nile } \\
\text { (El-Kanater } \\
\text { El-Khyria) }\end{array}$ & $\begin{array}{c}\text { Iron and } \\
\text { Steel Basin }\end{array}$ & \\
\hline Serum ALT (IU/l) & $\mathbf{9}$ & $\mathbf{1 4 3 . 4 0}$ & $\mathbf{2 0 9 . 6 0}$ & $\mathbf{2 . 3 6}$ & $\mathbf{0 . 6 8}$ & 0.00 \\
\hline Serum AST (IU/l) & $\mathbf{9}$ & $\mathbf{2 2 2 . 9 8}$ & $\mathbf{6 1 6 . 8 0}$ & $\mathbf{0 . 7 4}$ & $\mathbf{1 . 0 7}$ & 0.00 \\
\hline Serum Urea (mg/dl) & $\mathbf{9}$ & $\mathbf{1 6 . 8 7}$ & $\mathbf{2 1 . 4 0}$ & $\mathbf{0 . 1 6}$ & $\mathbf{0 . 5 1}$ & 0.001 \\
\hline Serum creatinine (mg/dl) & $\mathbf{9}$ & $\mathbf{0 . 6 9}$ & $\mathbf{0 . 8 5}$ & $\mathbf{0 . 0 2}$ & $\mathbf{0 . 0 4}$ & 0.016 \\
\hline
\end{tabular}

- $\mathrm{df}=$ degree of freedom, Std. Error = standard error of the mean, P-value =attained level of significance

- Bold Value $(\mathrm{P})>0.05$ - Italic Value $(\mathrm{P})<0.05$

Min and Kang (2008) reported that LDH and ALT play an important role in ammonia detoxification in fish, which increased due to exposure of high level of heavy metals. The activity of serum transaminases in freshwater fishes was significantly altered when water is polluted with different metals such as Zinc, copper and cadmium (Zikic et al., 1997). Wieser and Hinterleitner (1980) reported increased activities of ALT in serum of rainbow trout in response to sewage loading in rivers. 
Shakoori et al. (1990), found that hepatic AST and ALT were increased in freshwater fish, Cirrhinus marigala, toxicated with cadmium and copper for 7 days.

This study showed also that there is an increase in urea concentrations in serum of fish collected from polluted area (Iron and Steel Basin). They were generally higher than these from the control sample (River Nile at El-Kanater El-Khyria. The increases may be attributed to the heavy metal concentration in water especially copper and iron which cause a marked liver and renal diseases (El-Sabbagh, 1996). Serum creatinine was increased in fish collected from polluted sector compared to that in fish of unpolluted sector. Also, Hadi et al., (2009) found that creatinine and uric acid was significantly high with the increase of aluminum concentration in water. The increase of urea and creatinine concentrations may be refered to kidney failure and increased muscular tissue catabolism (Pandey et al., 2003). The rise in creatinine might be induced by glomerular insufficiency, increased muscle tissue catabolism or the impairment of carbohydrate metabolism (Sevgiler et al., 2004).

\section{CONCLUSION AND RECOMMENDATIONS}

Fish contaminated by heavy metals suffers pathological alterations, with consequent inhibition of metabolic processes, hematological changes, and decline in fertility and survival. It can be conclusively deduced from this study that the fresh water fish, Oreochromis niloticus has the tendency to bioaccumulate heavy metals in a polluted environment. Since virtually all metals investigated were found in higher concentration, so government should intact laws that will ensure that industries make use of standard waste treatment plants for the treatment of their wastes before they are being discharged into water bodies.

\section{ACKNOWLEDGMENTS}

The author appreciates the efforts of Prof. Dr. Maha Mahmoud Ali, for her unlimited support and kind encouragement. Appreciation is also extended to the staff of Central laboratory for Environmental Quality Monitoring.

\section{REFERENCES}

Abdelhamid, A.M. and El-Zareef, A.A.M. (1996). Further studies of the pollution status on the southern region of El-Manzalah Lake. Proc. Food Borne Contamination and Egyptian's Health Conference, 26 - 27 Nov., pp. $141-150$.

AbdelSatar, A. M. (1998). Distribution of some elements in River Nile environment at great Cairo Region. Ph. D. Thesis, Fac. Sci, Cairo Univ. Egypt.

Abdo, M. H. (2005). Physico-chemical characteristics of Abu Za'baal Ponds, Egypt. Egypt. J. Aquatic Res., 31(2): 1- 15.

Adakole, J.A. (2012). Changes in some haematological parameters of the African catfish (Clarias gariepinus) exposed to a metal finishing company effluent. Ind J. Sci. Technol., 4 (5): 2510-2514

APHA (American Public Health Association) (2005). Standard methods for examination of water and wastewater. 20th Ed. Washington, D C., P., 1193-2950.

Bolalak, J. and Frankowaski, L. (2003). Selected nutrients and iron in interstitial, water of the estuary of southern Baltic in relation to redox potential. Bull. Environ. Contam. Toxicol., 147:39 - 44. 
Bowden, T.J. (2008). Modulation of the immune system of fish by their environment. Fish Shellfish Immunol., 25:373-383.

Burden, V.M.; Sandheinrich M.B. and Caldwell, C.A. (1998). Effects of lead on the growth and alpha aminolevulinic acid dehydrates activity of juvenile vainbow trout, Oncorhynchus mykiss. Environ. Poll., 101: 285-289.

Buschiazzoa, E.; Metian, M.; Borne, V.; Cotret, O.; Teyssie, J. L.; Fowler, S.W. and Warnau, M. (2004). Influence of ambient dissolved metal concentration on their bioaccumulation in two tropical oysters. International conference on isotope in environmental studies, Monte Carlo (Monaco), 25 - 29.

Carbonell, G.; Romos, C. and Tarazone, J.V. (1998). Heavy metals in shrimp culture area from the Gulf of Fonseca. Central America. II. Cultured Shrimps. Pull. Inviron. Contm. Toxical., 60: 260-265.

Chandanshive, S.; Sarwade, P.; Atul, H. and Mohekar, A. (2012). Effect of heavy metal model mixture on haematological parameters of Labeo rohita from Gharni Dam Nalegaon, Lutur. Int multidisc Res. J., 2(4): 10- 12.

Clare, A. A.; Dianne F. J. and Stuart L. S. (2007). Effect of overlying water pH, dissolved oxygen, salinity and sediment disturbances on metal release and sequestration from metal contaminated marine sediments, Chemosphere 69 (9) p $1428-1437$.

Cogun, H.; Yuzereroglu, T.A.; Kargin, F. and Firat, O. (2005). Seasonal variation and tissue distribution of heavy metals in shrimp and fish species from the Yumurtalik coast of Iskenderun Gulf, Mediterranean. Bull. Environ. Contam. Topical., 75: 707-715.

Dave, G. and Xiu, R. (1991). Toxicity of mercury, copper, nickel, lead and cobalt to embryos and larval of Zebra fish Brachydanio rerio. Arch. Environ. Contam. Toxicol., 21: 126-134.

Doherty, V.F.;Ogunkuade, O.O. and Kanife, U.C. (2010). Biomarkers of oxidative stress and heavy metal levels as indicators of environmental pollution in some selected fishes in Lagos, Nigeria. American-Eurasian J. Agric. Environ Sci. 7 (3): 359- 365.

Dutta, T. K. and Kaviraj, A. (1996). Effects of lime acclimation on the susceptibility of two freshwater teleosts and one oligochaet worm to metabolic pollutant cadmium. Folia Biologica (Krakow), 44: 143-148.

El-Naggar, A. M.; Mahmoud, S. A. and Tayel, S. I. (2009). Bioaccumulation of Some Heavy Metals and Histopathological Alterations in Liver of Oreochromis niloticus in Relation to Water Quality at Different Localities along the River Nile, Egypt. World J. Fish and Mar. Sci., 1 (2): 105-114.

El-Sabbagh, H.S. (1996): Biochemical and hematological changes in tilapia nilotica, Oreochromis niloticus exposed to Copper. Vet. Med. J., 44(1): 23-30.

El-Sayed, A. E.; El-Ayyat, M. S.; Nasr, E. and Khater, Z. Z. K. (2011). Assessment of heavy metals in water, sediment and fish tissues, from Sharkia province, Egypt. Egypt. J. Aquat. Biol. \& Fish., 15(2): 125- 144

El-Sherbini, A.M.; Bary, M.R.A.; Heikal, M.T. and Hamdy, A. (1997). Environmental impacts of pollution sources on Rosetta Branch water quality, Volume II. Water quality and pollution control. Water management, salinity and pollution control towards sustainable irrigation in the Mediterranean region. CIHEAM International Conference, Valenzano, Bari, Italy, 22-26 September, pp. 65-85.

FAO (Food and Agriculture Organization) (1992). Committee for inland fisheries of Africa; Report of the third session of the working party on pollution and fisheries. Accra, Ghana. 25-29, November 1991. FAO fisheries. Rep., No. 471. 
Farombi, E.O.; Adelowo O.A. and Ajimoko Y.R. (2007). Biomarkers of oxidative stress and heavy metal levels as indicator of environmental pollution in African Catfish (Clarias gariepinus) from Nigeria Ogun River. Int. J. Environ. Res. Public Health 4: 158-165.

Fitzsimmons, K. (2000). Tilapia the most important aquaculture species of the $21 \mathrm{st}$ century. $5^{\text {th }}$ Int. symposium on tilapia aquaculture in the $21^{\text {st }}$ century. Brazil, 7 : 3-8.

Galloway, J. N.; Aber, J.D.; Erisman, J.W.; Seitzinger, S.P.; Howarth, R.W.; Cowling, E.B. and Cosby, B.J. (2003). The nitrogen cascade. Biosci. 53:341-356.

Godwin, T.H.; Young, A.; Holmes, M. O.; Hewitt, G. N.; Packman, G. J. and Smith, B. (2003). The Temporal and Spatial Variability of Sediment Transport and Yields within the Bradford Beck Catchment, West Yorkshire. Science of the Total Environment 314: 475-494

Hadi, A. A.; Shokr, A. E. and Alwan, S. F. (2009). Effects of aluminum on the biochemical parameters of fresh water fish, Tilapia zillii. J. sci. appli., 3(1): 33-41.

Haggag, A.M.; Marie, M.A.S.; Zaghloul, K.H. and Eissa, S.M. (1993). Treatment of underground water for fish culture in Abbassa Farm, Sharkia. Bull. Fac. Sci., Cairo Univ.

Hamed, M. A., (1998). Distribution of trace metals in the River Nile ecosystem Damietta Branch between Mansoura city and Damietta Province. J. Egypt. Ger. Soc. Zool. (A) Comp. physic., 27: 399-415.

Ibrahim, S.A. and Tayel, S.I. (2005). Effect of heavy metals on gills of Tilapia zillii inhabiting the River Nile water (Damietta branch) and El-Rahawy drain. Egypt. J. Aquat. Biol. and Fish, 9: 111-128.

Ibrahim, S.A. and Mahmoud, S.A. (2005). Effect of heavy metals accumulation on enzyme activity and histology in liver of some Nilefish in Egypt. J. Aquat. Biol. and Fish, 9: 203-219.

Javed, M. and Usmani, N. (2013). Haematological indices of Channa punctatus as an indicator of heavy metal pollution in waste water aquaculture pond, Panethi, India. Afri. J. of Biotech., 12(5): 520-525.

Kalay, M. and Canli, M. (2000) Elimination of essential (Cu and $\mathrm{Zn}$ ) and non essential $(\mathrm{Cd}$ and $\mathrm{Pb})$ metals from tissues of a fresh water fish, Tilapia zillii. Tropical Journal of Zoology 24:429-436.

Loigu, E. and Leisk, U. (1996). Water quality of rivers in the drainage basin of Lake Peipsi. Hydro. biol., 338: 25-35.

Matsuo, A.Y.; Playle, R.C.; Val, A.L. and Wood, C.M. (2004). Physiological action of dissolved organic matter in rainbow trout in the presence and absence of copper: sodium uptake kinetics and unidirectional flux rates in hard and soft water. Aquat. Toxicol. 18; 70(1):63-81

Mehjbeen, J. and Nazura, U. (2013). Assessment of heavy metals (Cu, Ni, Fe, Co, Mn, $\mathrm{Cr}, \mathrm{Zn}$ ) in rivulet water, their accumulations and alterations in hematology of fish Channa punctatus. Afri. J. of Biotech 13 (3). 492-501

Mersch, J.; Dubost, N. and Pihan, J. (1993). Comparison of several inert and biological substrates to assess the trace metals concentration in the reservoir of the nuclear power plant in catlenom. France. limnol., 29: 325-337.

Min, E. Y. and Kang, J. Ch. (2008). Effect of water borne benomyl on the hematological parameters of the Nile tilapia, Oreochromis niloticus. Pest. Biochem. \& Physiol., 92(3): 138-143. 
Ministry of Water Resources and Irrigation (1982). Protection of water ways from pollution Law 48/1982.

Mourad, M.; Abd-Allah, M. and Abd-Allah, A. (1999). Occurrence of heavy metals and its effects on some hematological and histological aspects of Tilapia zillii (Gerr). Bull. Nat. Inst. of Oceanogr. \& Fish., 25: 237 - 251.

Osman, A.; Wuertz, S.; Mekkawy, I.; Exner, H. and Kirschbaum, F. (2007). Lead Induced Malformations in Embryos of the African Catfish Clarias gariepinus (Burchell, 1822). Environmental Toxicology 22(4): 375-389.

Pandey, S.; Parvez, S.; Sayeed, I.; Haque, R.; Bin- Hafeez, B. and Raisuddin, S. (2003). Biomarkers of oxidative stress: a comparative study of river Yamuna fish Wallago attu. Sci. Total Environ., 309:105-15.

Praveena M.; Sandeep V.; Kavitha N. and Jayantha Rao K. (2013). Impact of Tannery Effluent, Chromium on Hematological Parameters in a Fresh Water Fish, Labeo Rohita (Hamilton). Res. J. Animal, Veterinary and Fishery Sci. Vol. 1(6), 1-5.

Rubio, R.; Tineo, P.; Torreblance, A.; Del-Romo, J. and Mayans, J.D. (1991). Histological and electron microscopical observations on the effects of lead on gills and midget gland of Procamarus Clarkii. Toxicol. Environ. Chem., 31: 347-352

Russo, R.C. and Thurston, R.V. (1991). Toxicity of ammonia, nitrite and nitrate to fishes. In aquaculture and water quality brune, D.E. \& tomasse, J. R. eds, P. 58-89.

Sabae. S. Z. and Rabeh, S. A. (2006). Evaluation of the microbial quality of the River Nile waters at Dameitta branch. Egypt., Egypt. J. Zool., 31: 312 - 319.

Schwarzenbach, R. P.; Gschwend, P. M. and Imboden. D. M. (2003). Environ. Organic Chemis., $2^{\text {nd }}$ Ed. 2003

Sevgiler, Y.; Oruc, E. O. and Uner, N. (2004). Evaluation of etoxazole toxicity in the liver of Oreochromis niloticus Pest. Biochem. \& Physiol., 78(1): 28-38.

Shah, S.L. (2006). Hematological parameters in Tinca tinca after short term exposure to lead. J. Appl. Toxicol., 26(3): 223-228.

Shakoori, A. R.; Ali, T.; Iqbal, M. J. and Ali, S. S. (2006). Cadmium induced biochemical changes in liver and muscle of a freshwater fish, Oreochromis niloticus. Proceedings of Pakistan congress of zoology, P.307-311.

Sharsher, M. M. (2011). Influence of effluent discharge on some microbiological and physicochemical aspects of Ismaalia Canal. Thesis for Master degree, Fac. of Sci. Banha Univ., Egypt.

Taiz, L. and Zeiger, E. (1998). Plant defenses: surface protectants and secondary metabolites. In: Taiz L and Zeiger E (eds.). Plant physiology. Sinauer Associates, Massachusetts. pp. 347-377.

Tayel, S.I.; Yacoub, A.M. and Mahmoud, S.A. (2008). Histopathological and haematological responses to freshwater pollution in the Nile catfish Clarias gariepinus. Journal of Egyptian Academic society for Environmental Development, 9: 43-60.

Wieser, W.; Hinterleitner, S. and Quintern, H. (1980). Serum-enzyme beri fischenals indikatoren der gewassergute osterreich fischerei Z. ges. fischerei, 33: 177-181.

Yacoub, A.M. (2007). Study on some heavy metals accumulated in some organs of three River Nile fishes from Cairo and Kalubia governorates. African J. Biol. Sci., 3: 9-21 
Zikic, R.V.; Stajn, A. S.; Ognjanovic, B.I.; Pavlovic, S.Z. and Saicicz, D. (1997). Activities of superoxide dismutase and catalase in erythrocytes and transaminase in the plasma of carps, cyprinus carpio L. exposed to cadmium. Physiol. Res., 46: $91-396$.

\section{ARABIC SUMMARY}

$$
\begin{aligned}
& \text { دراسة تأثير تراكم المعادن الثقيلة على التغيرات الهيماتولوجية فى سمكة البلطى النيلى } \\
& \text { السيد البسطامى السيا } \\
& \text { الباحث بالمركز القومى لبحوث المياه }
\end{aligned}
$$

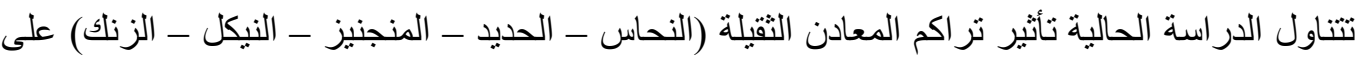

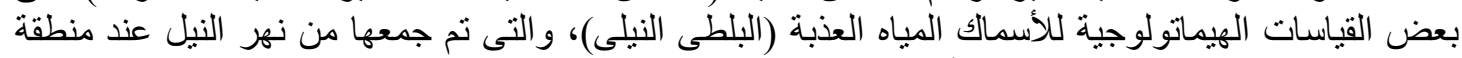

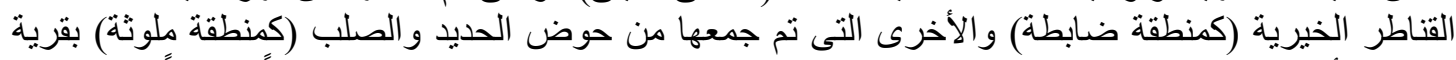

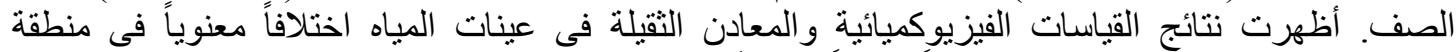

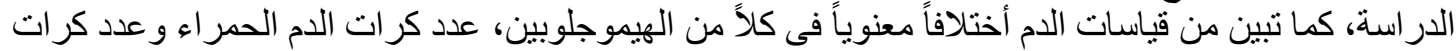

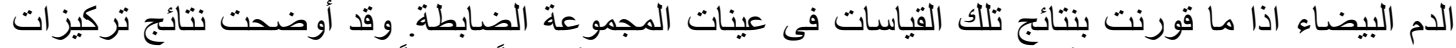

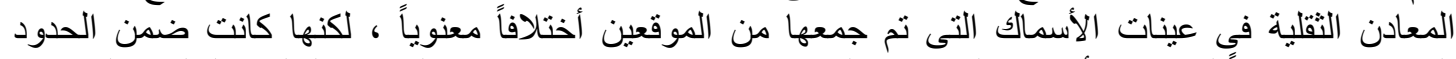

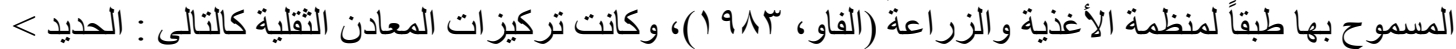

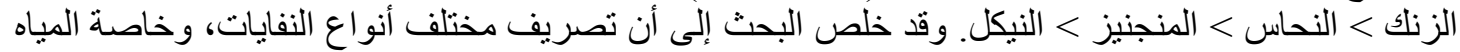

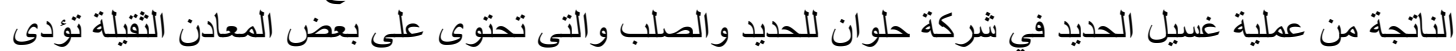

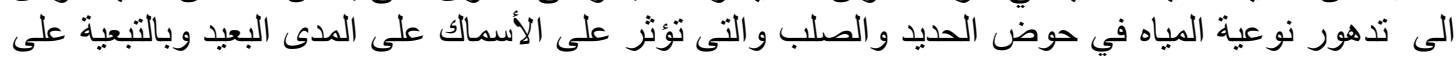

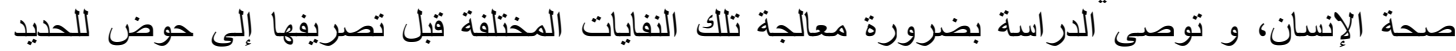

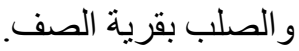

